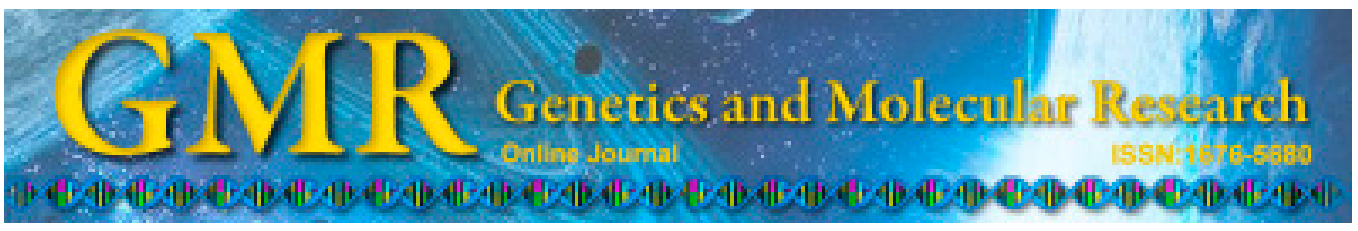

\title{
Novel polymorphic microsatellite markers in Odontobutis potamophila
}

\author{
Corresponding author: J.L. Li \\ E-mail: j1li2009@126.com \\ Genet. Mol. Res. 14 (2): 6265-6269 (2015) \\ Received September 18, 2014 \\ Accepted January 21, 2015 \\ Published June 9, 2015 \\ DOI http://dx.doi.org/10.4238/2015.June.9.13
}

Y.B. Shen ${ }^{1}$, D. Li ${ }^{1}$, J.L. Li ${ }^{1,2}$, R.Q. Wang ${ }^{3}$ and Y.F. Xuan ${ }^{3}$

${ }^{1}$ Key Laboratory of Freshwater Fishery Germplasm Resources, Ministry of Agriculture, Shanghai Ocean University, Shanghai, China ${ }^{2}$ E-Institute of Shanghai Universities, Shanghai Ocean University, Shanghai, China ${ }^{3}$ Key Laboratory of Conventional Freshwater Fish Breeding and Health Culture Technology Germplasm Resources, Ministry of Agriculture, Suzhou Wujiang Area Aquaculture Limited Company, Suzhou, China

\begin{abstract}
We characterized 16 novel polymorphic loci isolated from a partial genomic DNA library of Odontobutis potamophila enriched for CA repeats. We tested the variability of these microsatellites on 51 unrelated individuals collected in China. All loci were polymorphic. The average allele number was 14.6 per locus, ranging from 2 to 27 . The observed heterozygosity ranged from 0.35 to 0.90 , with an average of 0.70 , whereas the average expected heterozygosity was 0.76 . Twelve of the 16 microsatellites conformed to Hardy-Weinberg equilibrium and were inherited independently. These developed microsatellites will be useful in
\end{abstract}


studies of population genetics and other genetic studies on this important food species.

Keywords: Odontobutis potamophila; Microsatellite; Polymorphism

\section{INTRODUCTION}

Dark Sleeper Odontobutis potamophila is a freshwater benthopelagic fish that is widely distributed in the waters of China and Viet Nam (Wu et al., 1993). This species has been investigated for farming in recent years, and studies have been carried out on reproduction, larvae rearing, and performance (Liu et al., 2008; Zhao et al., 2009). Genetic and molecular-based research on this fish is limited (Hou et al., 2014). Microsatellites are codominant, highly polymorphic, and ideal for studies of genetic diversity (Goldstein and Schlotterer, 1999). Zhang et al. (2014) developed 42 polymorphic microsatellite markers for this fish from ESTs. In this study, we developed and characterized 16 novel polymorphic microsatellites isolated from $O$. potamophila genome. These markers can be useful to describe the levels of genetic diversity and population structure within and among populations and can be applied in other genetic studies (e.g., parentage assignment) in this species.

\section{MATERIAL AND METHODS}

Total genomic DNA was extracted from a small piece of fin clip from one fish individual following a standard phenol-chloroform protocol (Sambrook et al., 1989). All PCR protocols carried out in this study were conducted on Mastercycler Eppendorf PCR machines (Eppendorf AG, Hamburg, Germany).

A partial genomic library enriched for CA-repeats (Fischer and Bachmann, 1998) was constructed with some modification (Yue et al., 2000). Briefly, approximately 300 ng genomic DNA was digested with $R s a \mathrm{I}$ restriction enzyme (NEB) at $37^{\circ} \mathrm{C}$ for $2 \mathrm{~h}$. DNA fragments (200-1000 bp) were ligated with an adapter produced by hybridizing a 5'-phosphorylated 25- and 21-mer oligonucleotides (Edwards et al., 1996). Ligated DNA was amplified with PCR using the 21-mer oligonucleotide and following the program of 1 cycle at $95^{\circ} \mathrm{C}$ for $3 \mathrm{~min}, 56^{\circ} \mathrm{C}$ for $1 \mathrm{~min}$, and $7^{\circ} \mathrm{C}$ for $2 \mathrm{~min} ; 28$ cycles at $94^{\circ} \mathrm{C}$ for $30 \mathrm{~s}$, $56^{\circ} \mathrm{C}$ for $30 \mathrm{~s}$, and $72^{\circ} \mathrm{C}$ for $1 \mathrm{~min}$; and the final step at $72^{\circ} \mathrm{C}$ for $10 \mathrm{~min}$. After denaturation at $98^{\circ} \mathrm{C}$ for $5 \mathrm{~min}$, the PCR products were hybridized with a $5^{\prime}$-biotinylated probe $(\mathrm{CA})_{10}$ in $300 \mu \mathrm{L}$ hybridization solution (6X SSC, $0.1 \% \mathrm{SDS}, 0.5 \mu \mathrm{M}$ probe) at $55^{\circ} \mathrm{C}$ for 20 min. Subsequent probe-bound DNA fragments were enriched for CA repeats using streptavidin-coated magnetic beads (Promega, Madison, WI, USA) at room temperature for $30 \mathrm{~min}$, followed by two washing steps. Recovered DNA fragments were amplified with the 21-mer adaptors (5'-CTCTTGCTTACGCGTGGACTA-3') as primer. The PCR 
products were purified with a Gel Extraction Kit (TaKaRa, Tokyo, Japan) and ligated to pGEM-T Easy vector (MBI-Fermentas, Vilnius, Lithuania) followed by transformation in Escherichia coli DH5 $\alpha$ competent cells (Invitrogen, Carlsbad, CA, USA). Recombinant clones were amplified from the plasmid DNA using universal primer, and inserted fragment lengths were visualized with $1.5 \%$ agarose gel electrophoresis. The putative cloned fragments were sequenced in both directions using M13 forward and reverse primers in an ABI3730xl automated sequencer (Applied Biosystems, Foster City, CA, USA). Forward and reverse sequences were assembled using the SEQUENCHER version 4.10 sequence analysis software (GeneCodes Corporation, Ann Arbor, MI, USA, http://www.genecodes.com).

Primers were designed using the Primer 5.0 software (Premier Biosoft International, Palo Alto, CA, USA). One primer of each pair was labeled with a fluorescent dye FAM (Table 1). With a subset of templates (three fish), the annealing temperature was optimized for each pair of primers. Microsatellite loci were characterized with 51 individuals of $O$. potamophila collected in Jiangsu Province, China. The concentrations of the reaction volumes were as follows: $40 \mathrm{ng}$ genomic DNA, 0.5 U Taq Polymerase (TaKaRa), 1X PCR buffer, $0.2 \mathrm{mM}$ of each primer, $0.2 \mathrm{mM}$ of each dNTP, $2.0 \mathrm{mM} \mathrm{Mg}^{2+}$, and $\mathrm{ddH}_{2} \mathrm{O}$ in a final volume of $25 \mu \mathrm{L}$. PCR thermal conditions were as follows: initial denaturation step of $2 \mathrm{~min}$ at $94^{\circ} \mathrm{C}$, followed by 35 cycles of $30 \mathrm{~s}$ at $94^{\circ} \mathrm{C}, 30 \mathrm{~s}$ at the annealing temperature listed in Table 1 , and $1 \mathrm{~min}$ at $72^{\circ} \mathrm{C}$, followed by the final extension step at $72^{\circ} \mathrm{C}$ for $10 \mathrm{~min}$. The PCR products were electrophoresed on an automated DNA sequencer ABI 3730xl (Applied Biosystems), and fragment size of alleles was determined against the size standard ROX-500 using the GENEMAPPER software (Applied Biosystems). Allele number, observed and expected heterozygosities, conformation of Hardy-Weinberg, and linkage disequilibria were estimated by using POPGENE version 1.32 (Yeh et al., 1999).

\section{RESULTS AND DISCUSSION}

Fifty clones containing microsatellites were obtained in this study. Of the amplified sequences, 32 contained enough flanking regions and 32 primer pairs were designed using the Primer 5.0 software (Premier).

All 16 microsatellite loci showed polymorphism in the population. The average allele number of these markers was 14.6 per locus, with a range of 2 to 27 alleles per locus. The observed heterozygosity ranged from 0.35 to 0.90 with an average of 0.70 , whereas the expected heterozygosity averaged at 0.76 , ranging from 0.38 to 0.92 . Due to null alleles, significant departure from Hardy-Weinberg equilibrium was observed in four of 16 loci in the population: Oo02, Oo04, Oo10, Oo16 (Table 1). All 16 markers showed no linkage. Until recently, there have been no specifically designed DNA markers such as microsatellites available for this fish. Thus, these 16 microsatellite primer pairs will facilitate studies on genetic diversity and population structure of the $O$. potamophila, which is essential for conservation of the wild stocks. 
Table 1. Sixteen novel microsatellites from Odontobutis potamophila.

\begin{tabular}{|c|c|c|c|c|c|c|c|c|}
\hline $\begin{array}{l}\text { Locus } \\
\text { GenBank No. }\end{array}$ & $\begin{array}{c}\text { Repeat } \\
\text { motif }\end{array}$ & Primer sequence $\left(5^{\prime}-3^{\prime}\right)$ & $\mathrm{Ta}\left({ }^{\circ} \mathrm{C}\right)$ & $\begin{array}{l}\text { No. of } \\
\text { alleles }\end{array}$ & $\begin{array}{c}\text { Size } \\
\text { range (bp) }\end{array}$ & $H_{\mathrm{o}}$ & $H_{\mathrm{E}}$ & $P_{\mathrm{HWE}}$ \\
\hline $\begin{array}{l}\text { Oo01 } \\
\text { KC890856 }\end{array}$ & $(\mathrm{AC})_{11}$ & $\begin{array}{l}\text { FAM-TCCTCTGTGGGCAGTTGTAG } \\
\text { ATAGTCTCCGCAGATTGTGA }\end{array}$ & 55 & 19 & $307-359$ & 0.61 & 0.74 & 0.01 \\
\hline $\begin{array}{l}\text { Oo02 } \\
\text { KC890857 }\end{array}$ & $(\mathrm{CA})_{11}$ & $\begin{array}{l}\text { FAM-AGTGACAGCCACAGACAGCA } \\
\text { AAGGGAATTAGCCTAGAACG }\end{array}$ & 55 & 27 & $205-237$ & 0.84 & 0.92 & 0.73 \\
\hline $\begin{array}{l}\text { Oo03 } \\
\text { KC890858 }\end{array}$ & $(\mathrm{TG})_{9}$ & $\begin{array}{l}\text { FAM-TTGACAACAGCGTCTTCCCACT } \\
\text { CGATGACATCATTGCCGAGA }\end{array}$ & 55 & 19 & $206-262$ & 0.80 & 0.87 & 0.02 \\
\hline $\begin{array}{l}\text { Oo04 } \\
\text { KC } 890859\end{array}$ & $(\mathrm{CA})_{7}$ & $\begin{array}{l}\text { FAM-TGTTTTCTCCAGGTGGTGTTC } \\
\text { ACCCTCCCTTTATGAGTTGTG }\end{array}$ & 55 & 2 & $248-254$ & 0.35 & 0.38 & 0.56 \\
\hline $\begin{array}{l}\text { Oo05 } \\
\text { KC } 890860\end{array}$ & $(\mathrm{CA})_{9}$ & $\begin{array}{l}\text { FAM-TCTTCCCTCCTCCTTCTTCT } \\
\text { AGGTGCTGATTGTCTTTTGA }\end{array}$ & 55 & 8 & $338-354$ & 0.59 & 0.61 & 0.01 \\
\hline $\begin{array}{l}\text { Oo06 } \\
\text { KC890861 }\end{array}$ & $(\mathrm{TG})_{12}$ & $\begin{array}{l}\text { FAM-GAAGGAAATGGAGGGAGACA } \\
\text { TCAACAGGTAATTGGGCTTG }\end{array}$ & 55 & 6 & $332-353$ & 0.41 & 0.61 & 0.02 \\
\hline $\begin{array}{l}\text { Oo0 } 07 \\
\text { KC } 890862\end{array}$ & $(\mathrm{GT})_{11}$ & $\begin{array}{l}\text { FAM-CAGCAGCATTCAATCACTACAA } \\
\text { TCTAACAACATCCATTCGTCCT }\end{array}$ & 55 & 17 & $299-355$ & 0.90 & 0.88 & 0.00 \\
\hline $\begin{array}{l}\text { Oo0 } 08 \\
\text { KC } 890863\end{array}$ & $(\mathrm{TG})_{21}$ & $\begin{array}{l}\text { FAM-GTGTTTGCTATGTCCCACCAT } \\
\text { TGTAGTCTTTCCCTGGCTTTT }\end{array}$ & 55 & 16 & $208-276$ & 0.90 & 0.88 & 0.00 \\
\hline $\begin{array}{l}\text { Oo09 } \\
\text { KC } 890864\end{array}$ & $(\mathrm{TG})_{25}$ & $\begin{array}{l}\text { FAM-TCTCATTGAACCGCTGATT } \\
\text { ACTCCCATAGCCTTTGACC }\end{array}$ & 60 & 13 & $180-206$ & 0.74 & 0.65 & 0.00 \\
\hline $\begin{array}{l}\text { Oo10 } \\
\text { KC } 890865\end{array}$ & $(\mathrm{AG})_{21}$ & $\begin{array}{l}\text { FAM-ACGCACAACACGTCAAACCCTG } \\
\text { TAAGTTATGGCTGAAGACAAAC }\end{array}$ & 55 & 13 & $263-303$ & 0.82 & 0.85 & 0.55 \\
\hline $\begin{array}{l}\text { Oo11 } \\
\text { KC890866 }\end{array}$ & $(\mathrm{TG})_{11}$ & $\begin{array}{l}\text { FAM-TTGGGACGGACCTGATGTTG } \\
\text { TCATTGGGAAACTGGGCTGA }\end{array}$ & 55 & 19 & $223-292$ & 0.90 & 0.92 & 0.00 \\
\hline $\begin{array}{l}\text { Oo12 } \\
\text { KC890867 }\end{array}$ & $(\mathrm{TG})_{14}$ & $\begin{array}{l}\text { FAM-CAGATTCTTGATCCGCTTCC } \\
\text { ATAGCAGAGTTGTGCCGTGA }\end{array}$ & 55 & 11 & $203-228$ & 0.66 & 0.81 & 0.00 \\
\hline $\begin{array}{l}\text { Oo13 } \\
\text { KC890868 }\end{array}$ & $(\mathrm{GA})_{26}$ & $\begin{array}{l}\text { FAM-GACCAGGTGTTGGTGTTTGA } \\
\text { GCATGAGCTTCCCAGTTTCC }\end{array}$ & 55 & 19 & $218-259$ & 0.74 & 0.88 & 0.00 \\
\hline $\begin{array}{l}\text { Oo14 } \\
\text { KC } 890869\end{array}$ & $(\mathrm{TG})_{10}$ & $\begin{array}{l}\text { FAM-ACAAGAGCCAACGCAAGTCAG } \\
\text { TTTCAGCAAACAATGTCCCAC }\end{array}$ & 55 & 21 & $342-380$ & 0.72 & 0.90 & 0.01 \\
\hline $\begin{array}{l}\text { Oo15 } \\
\text { KC } 890870\end{array}$ & $(\mathrm{GT})_{12}$ & $\begin{array}{l}\text { FAM-ATAACCCGCTGATGCAGACCA } \\
\text { TAGCCCAGCAGCACTATCTCA }\end{array}$ & 60 & 13 & 218-306 & 0.45 & 0.54 & 0.00 \\
\hline $\begin{array}{l}\text { Oo16 } \\
\text { KC890871 }\end{array}$ & $(\mathrm{TG})_{14}$ & $\begin{array}{l}\text { FAM-TCCTGCTGCTTATGTTTGGTGT } \\
\text { TTTCGCCTTTGTCTGTTTGTCT }\end{array}$ & 55 & 11 & $212-273$ & 0.72 & 0.78 & 0.26 \\
\hline
\end{tabular}

Ta, Annealing temperature applied for PCR; $H_{\mathrm{O}}$, observed heterozygosity; $H_{\mathrm{E}}$, expected heterozygosity; $P_{\mathrm{HWE}}$, significance of deviation from Hardy-Weinberg equilibrium.

\section{ACKNOWLEDGMENTS} (\#ZF1206).

Research supported by the Shanghai Universities Knowledge Service Platform

\section{REFERENCES}

Edwards KJ, Barker JHA, Daly A, Jones C, et al. (1996). Microsatellite libraries enriched for several microsatellite sequences in plants. Biotechniques 20: 758-760.

Fischer D and Bachmann K (1998). Microsatellite enrichment in organisms with large genomes (Allium cepa L.). Biotechniques 24: 796-802.

Goldstein DB and Schlotterer C (1999). Microsatellites: evolution and applications. Oxford University Press, London.

Hou X, Zhu F, Ying S, Zhang L, et al. (2014). Genetic diversity of Odontobutis potamophila from different geographic populations inferred from mtDNA control region. Mitochondrial DNA 25: 400-406.

Liu M, Hu X, Han Q and Luo Y (2008). Variation of the proteinic enzymes activities during the embryonic and larval development of Odontobutis potamophila. Freshwater Fish 38: 39-41.

Sambrook J, Fritsch EF and Maniatis T (1989). Molecular cloning: a laboratory manual, second ed., Cold Spring Harbor, NY.

Wu H, Wu X and Xie Y (1993). A revision of the genus Odontobutis from China with description of a new species. $J$. Shanghai Fish. Univ. 2: 52-61. 
Yeh F, Yang RC and Boyle T (1999). POPGEN version 1.32: the user friendly software for population genetic analysis. Molecular Biology and Biotechnology Centre, University of Alberta, Edmonton, AB, Canada. Available at [http:// www.ualberta.ca/ fyeh/popgene_download.htm].

Yue GH, Chen F and Orban L (2000). Rapid isolation and characterization of microsatellites from the genome of Asian arowana (Scleropages formosus, Osteoglossidae, Pisces). Mol. Ecol. 9: 1007-1009.

Zhang L, Zhang H, Zhang Y, Zhu F, et al. (2014). Development and characterization of 42 novel polymorphic microsatellite markers for Odontobutis potamophila from EST sequences. Conserv. Genet. Resour. 6: 469-472.

Zhao X, Chen L, Gu Z, Li E, et al. (2009). Effects of starvation on ovarian development in female Odontobutis potamophila during over-wintering period. J. Fish. China 33: 70-77. 